\title{
Influence of Mining Activities on Arsenic Concentration in Rice in Asia: A Review
}

\author{
Anh T. P. Hoang ${ }^{1}$, Nouvarat Prinpreecha ${ }^{1,2}$ and Kyoung-Woong Kim ${ }^{1, *(D)}$ \\ 1 School of Earth Sciences \& Environmental Engineering (SESEE) and International Environmental Research \\ Institute (IERI), Gwangju Institute of Science and Technology (GIST), Gwangju 61005, Korea; \\ phuonganhhoang@gm.gist.ac.kr (A.T.P.H.); n.prinpreecha@gmail.com (N.P.) \\ 2 Mineral Resources Regional Office 3, Department of Mineral Resources, Ministry of Natural Resources and \\ Environment, Pathum Thani 12120, Thailand \\ * Correspondence: kwkim@gist.ac.kr
}

Citation: Hoang, A.T.P.; Prinpreecha, N.; Kim, K.-W. Influence of Mining Activities on Arsenic Concentration in Rice in Asia: A Review. Minerals 2021, 11, 472. https://doi.org/ $10.3390 / \min 11050472$

Academic Editor: Anna H. Kaksonen

Received: 15 March 2021

Accepted: 27 April 2021

Published: 30 April 2021

Publisher's Note: MDPI stays neutral with regard to jurisdictional claims in published maps and institutional affiliations.

Copyright: (c) 2021 by the authors. Licensee MDPI, Basel, Switzerland. This article is an open access article distributed under the terms and conditions of the Creative Commons Attribution (CC BY) license (https:// creativecommons.org/licenses/by/ $4.0 /)$.
Abstract: Crop and livestock farming on contaminated soil has been found to induce the accumulation of trace elements in edible parts of plants, with subsequent risk to human and animal health. Since rice crop is a major source of energy in worldwide diets and is consumed by more than 3 billion people, the soil-rice pathway is regarded as a prominent route of human exposure to potentially toxic elements. This study provides an overview of arsenic contamination in paddy rice from mining-impacted areas in several Asian countries that are primary rice consumers. From this review, it may be concluded that mining activities, along with the associated residual waste, significantly contribute to arsenic contamination of this food crop as rice samples from these regions were highly contaminated, with the highest total arsenic concentrations recorded being 3-4 times higher than the maximum levels proposed by the Codex Alimentarius Commission. While the contamination in China, Korea, Indonesia, and Thailand appeared to be slightly affected by mining activities, the elevated levels of arsenic in rice from mining areas in India, Bangladesh, and Vietnam could be derived from arsenic-contaminated groundwater.

Keywords: arsenic; rice; mining areas

\section{Introduction}

Rice, an essential grain food for more than half of the world's population, is cultivated in more than 100 countries, with $90 \%$ of the total global production in Asia [1]. Rice is frequently eaten, especially by children, due to being a high-calorie, generally lowcost food with bland taste, high iron content, and relatively low allergic potential [2]. According to the FAO report in 2018, 503.9 million tonnes of rice was produced in 2017 worldwide, with China leading global rice production with nearly 210 million tonnes, followed by India, Indonesia, and Bangladesh [3]. However, as crop ingestion is the primary exposure pathway for humans to toxic elements, cultivating crops on contaminated land can potentially accelerate the uptake and accumulation of trace metals, especially arsenic, in edible plant parts, and subsequently present a potential health risk to local residents [4]. In addition, the level of arsenic accumulation from soil and water in rice is substantially higher than in other crops, as the anaerobic condition of paddy fields promotes the availability of inorganic arsenic for plant uptake, resulting in 10-fold higher concentrations in rice grain, in comparison with aerobically grown grains such as wheat or barley $[2,5]$.

Industrial development is associated worldwide with the extraction and distribution of mineral substances from their natural deposits. In mining-impacted sites, arsenic is generally measured at elevated levels that cause health and ecological hazards. Abandoned metal mines are one significant source of arsenic contamination of the environment, as the activities of heavy rainfall and strong winds facilitate arsenic transportation via downstream movement from the vicinity of mining sites, leading to the release of massive 
quantities of arsenic into paddy fields through irrigation water contaminated by mining and smelting operations [6].

Numerous studies have evaluated the arsenic content of paddy soil and rice in the vicinity of mining sites - as well as the regional variability of arsenic concentration in this essential crop plant-in order to assess the potential health risk. In this review, these reports are merged to describe the exposure levels surrounding mining areas, with particular reference to case studies from China, India, Bangladesh, Indonesia, Thailand, Vietnam, and South Korea, to provide a broader perspective of the regional situation of arsenic contamination in rice.

\section{China Case Study}

China ranks first in rice production and consumption worldwide, representing about $30 \%$ of the total global rice output [7]. Rice is also the most popular food in China, and the history of rice planting in China goes back to the seventh millennium BC [8]. However, as the country with the world's largest population, China unquestionably faces great demand for rice, as well as other necessities. In recent decades, metal consumption in China has accounted for an increasing share of the global demand for iron ore, copper, nickel, and zinc, while the country is also a major mineral producer. Nevertheless, mining activities have generated enormous wasteland areas and caused serious pollution to the country [9], leading to the Chinese government closing down nearly 1000 inefficient, polluting iron ore mines in 2017 [10].

Being fortunate in possessing a suitable climate for paddy farming and a long history of cultivation, Hunan has grown into the largest rice-producing province in China, with its rice yield contributing $13 \%$ of the total yield of the country [11]. Nevertheless, the region is also viewed as a pollution hotspot within the country, with non-ferrous mining, lead-zinc ore mining, and smelting activities. Hunan contains over 140 mineral deposits, with an exploitation history of more than 2700 years [7]. Table 1 illustrates that the mean values of total arsenic concentration in unpolished rice samples in the mining areas of Hunan province ranged from 0.29 to $1.04 \mathrm{mg} / \mathrm{kg}$, considerably higher than that from nonimpacted sites $(0.063 \mathrm{mg} / \mathrm{kg})$, with the worst contamination coming from the vicinity of the Chenzhou mine, and the cluster of the Shizhuyuan, Dongbo, and Manaoshan mines in Suxian County. While the mean arsenic levels in soils of various countries generally ranged from 0.1 to $40 \mathrm{mg} / \mathrm{kg}$, the figure from agricultural lands in Suxian was $379.9 \mathrm{mg} / \mathrm{kg}$ [12]. In the 1985 case of the Chenzhou lead/zinc mine, the mine tailing dam collapsed due to heavy rain, causing a layer of black sludge, of about $15 \mathrm{~cm}$ thickness, to cover a strip of farmland. Despite the fact that-after the foundation failure-emergency soil clean-up procedures were promptly conducted at several sites, most of the contaminated farmlands are still overlaid with spills, and, to this day, parts of them have been utilized for agricultural activities [13]. Consequently, the results from the vicinity of the Suxian and Chenzhou mines are over 3 times higher than the maximum level that the Codex Alimentarius Commission proposes for arsenic in husked rice $(0.35 \mathrm{mg} / \mathrm{kg})$ [14]. The highest total arsenic concentration in Hunan was found near the Shimen realgar mine. It is the largest realgar deposit in Asia with more than 1500 years of mining history [15]. Intensive mining activities have left behind a large amount of mining waste, leading to the arsenic content of topsoil in the vicinity of the mine being over 5 times higher than that of the background value in Hunan province. Li et al. (2010) reported that arsenic concentration in rice from near the mining site was over 3 times higher than that of rice from the control area [16], the consumption of which can lead to serious consequences.

Guangdong province has one of the most prosperous economies in China. However, its rapid economic and industrial development has caused the region to become one of the most heavy metal-polluted areas in the country. In the $\mathrm{Pb}-\mathrm{Zn}$ mine-affected regions of Renhua and Lechang of the province, Li et al. reported a wide range of arsenic concentrations in soil, from 3.7 to $120.3 \mathrm{mg} / \mathrm{kg}$, with a mean value of $30.4 \mathrm{mg} / \mathrm{kg}$ [17]. Table 1 shows that the total arsenic level of unpolished rice from mining-impacted areas in Guangdong province 
varied between 0.19 and $0.564 \mathrm{mg} / \mathrm{kg}$, which was lower than that of rice from Hunan province, yet generally higher in comparison with samples from non-impacted sites of the region (Huahang-Simiao cultivar). The highest concentration of the region was recorded near the Lianhuashan mine, with a range of 0.152 to $1.094 \mathrm{mg} / \mathrm{kg}$. Located in Shantou city, it is one of the largest tungsten mines in China, and arsenic-containing acid drainage generated from the site is the main precursor to the significant inflow, contaminated with arsenic, towards the downstream environment of the mining area [18]. Several studies examined the degree of arsenic contamination in crop plants in the vicinity of this mine, and the results showed that the maximum value remained unchanged in the period of 2006 to 2011; however, there was a decrease from 0.564 to $0.32 \mathrm{mg} / \mathrm{kg}$ in the mean value, which is a positive tendency of the region.

Table 1. Total arsenic concentration in husked rice sampled from mining areas in China.

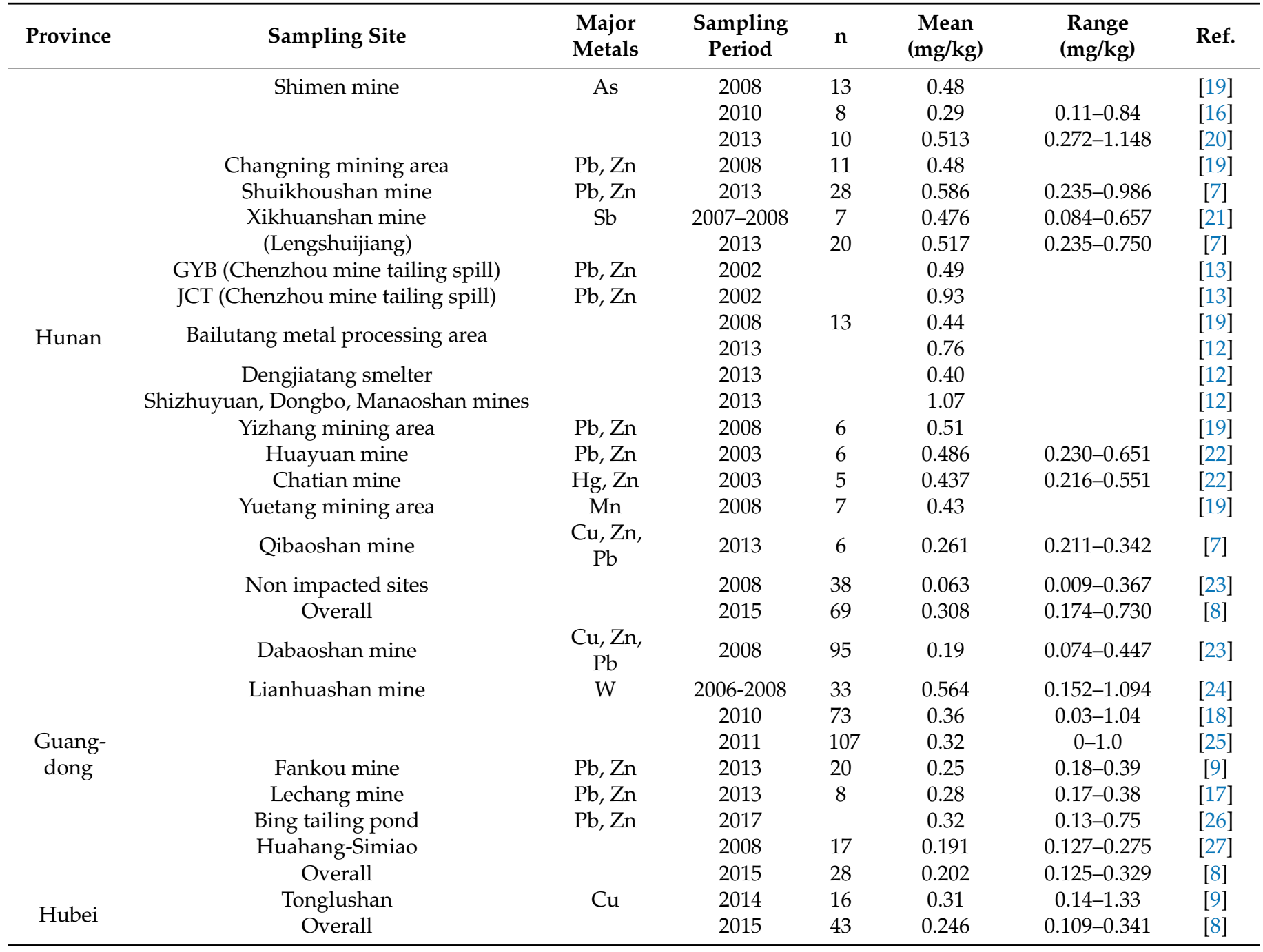

Of all the mining-impacted areas listed, samples from the Tonglushan mine held the highest maximum value of arsenic concentration in rice at $1.33 \mathrm{mg} / \mathrm{kg}$, which is nearly 4 times higher than the Codex Alimentarius Standard for husked rice. This mine is located in the northeast of Daye city (Hubei province), which is one of the largest copper basins in China. Mining activities of the Tonglushan mine have been in operation for more than 3000 years, generating considerable amounts of hazardous waste, without proper treatment [9]. The mean value of arsenic concentration in unpolished rice from the vicinity of this area was $0.31 \mathrm{mg} / \mathrm{kg}$, which is higher than the overall level of Hubei province $(0.246 \mathrm{mg} / \mathrm{kg})$. 
In addition, the general arsenic contamination in Hubei appeared to be less serious than that in Hunan and Guangdong provinces.

\section{India Case Study}

According to the 2015-2016 Annual Report from the Indian Ministry of Agriculture and Farmers Welfare, India ranks as the second largest rice producer and consumer worldwide, and accounts for $22.3 \%$ of global production. Rice is one of the most crucial cereal crops of India, occupying an area of 43.39 million hectares, with an annual production of 104.32 million tonnes, and an average productivity of $2404 \mathrm{~kg} / \mathrm{ha}(2015-2016)$ [28]. India also has a rich mining heritage from ancient times, which continues to the present day [29]. The country produces approximately 84 minerals with a cumulative production in 1999-2000 of 550 million tonnes, from more than 3100 mines producing coal, lignite, limestone, iron ore, bauxite, copper, lead, and zinc [30].

The Singhbhum Copper Belt of Jharkhand, the largest repository of copper ores known to date in India, is located in the east of the country [31]. Giri et al. (2017) reported that the mean values for total arsenic content of unpolished rice samples in mining areas in this region ranged from 0.008 to $0.162 \mathrm{mg} / \mathrm{kg}$, with the highest concentration recorded in the vicinity of the Ghatsila mine [32]. Table 2 also reveals that, in general, rice samples from sites that are closer to mining areas are more contaminated with arsenic than those from sites that are more distant (Bhatin, Kuldiha, Darisai).

However, in comparison with West Bengal, which is the largest rice producing state in India [33], the contamination situation in Singhbhum Copper Belt is less serious. Lying within the Ganga-Brahmaputra delta basin, West Bengal has been reported to have a high degree of arsenic contamination in groundwater since 1987 [34]. The accumulation of arsenic in rice grain in Boro season (harvested in May-June) was found to be notably higher than that from the Singhbhum Copper Belt, with a range of mean values from 0.23 to $0.54 \mathrm{mg} / \mathrm{kg}$. Similarly, a study on the influence of arsenic on Terai district in Nepal by Shrestha et al. (2017) showed that the average level of total arsenic in rice grain was relatively high, at $0.75 \mathrm{mg} / \mathrm{kg}$, as the ground water in both countries had been severely impacted by arsenic contamination in the Ganga-Meghna-Brahmaputra plain [35].

Table 2. Total arsenic concentration in rice sampled from mining areas in India and the West Bengal region.

\begin{tabular}{|c|c|c|c|}
\hline Location & Sampling Site & $\mathbf{n}$ & Mean $(\mathrm{mg} / \mathrm{kg})$ \\
\hline \multirow{14}{*}{ Singhbhum Copper Belt, [32] } & Bhatin & 3 & 0.008 \\
\hline & Kuldiha & 3 & 0.096 \\
\hline & Darisai & 3 & 0.071 \\
\hline & Bodamdera (Rakha mine vicinity) & 3 & 0.017 \\
\hline & Rakha (Rakha mine vicinity) & 3 & 0.080 \\
\hline & Jagganathpur & 3 & 0.033 \\
\hline & Kendadih (Kendadih mine vicinity) & 3 & 0.112 \\
\hline & Terenga (Kendadih mine vicinity) & 3 & 0.142 \\
\hline & Benashol (Kendadih mine vicinity) & 3 & 0.142 \\
\hline & Kutludih (Maubhandar mine vicinity) & 3 & 0.056 \\
\hline & Chirugoda (Ghatsila mine vicinity) & 3 & 0.162 \\
\hline & Pathergoda (Surda mine vicinity) & 3 & 0.067 \\
\hline & Latia (Badia, Mosabani mine vicinity) & 3 & 0.064 \\
\hline & Badia (Badia, Mosabani mine vicinity) & 3 & 0.127 \\
\hline \multirow{6}{*}{ Nadia district, West Bengal, [36] } & Chakdaha & 18 & 0.23 \\
\hline & Ranaghat-I & 12 & 0.30 \\
\hline & Shantipur & 12 & 0.40 \\
\hline & Krishnanagar & 12 & 0.24 \\
\hline & Haringhata & 9 & 0.54 \\
\hline & Contai (control site) & 5 & 0.05 \\
\hline
\end{tabular}




\section{Bangladesh Case Study}

Bangladesh has an agriculture-based economy, with nearly half of its population employed in this industry. Rice, as the dominant crop, covers nearly three-quarters of the cultivated area and contributes $70 \%$ of crop production value [37]. Meanwhile, the mineral industry represents only a minor part of the economy of Bangladesh. The country lacks reserves of metallic minerals but has large potential for the occurrence of coal, natural gas, and petroleum [38].

Of the five coal reserve basins discovered in Bangladesh, Barapukuria is the only active coal mine in the country. The mine is located in Dinajpur district, in the northwestern part of Bangladesh, covering more than $5 \mathrm{~km}^{2}$ within a wide flood plain [39]. In order to avoid flooding, $1500 \mathrm{~m}^{3}$ of water are discharged from the mine every hour and disposed of in a canal close to paddy fields, leading to the accumulation of potentially toxic elements in sediments and water in the vicinity of the mine [40,41]. Halim et al. (2015) reported that the arsenic level in rice grain from the area adjacent to the Barapukuria mine was $1.03 \mathrm{mg} / \mathrm{kg}$ [42], approximately 16 times higher than the mean value of total arsenic concentration from 40 polished rice samples from Dinajpur district, and much higher than the mean level of 965 polished rice samples from different districts of Bangladesh $(0.126 \mathrm{mg} / \mathrm{kg})$ [43].

In addition, Bangladesh also lies in the Ganga-Meghna-Brahmaputra plain and, similarly to India, contains groundwater highly contaminated with arsenic. During 1998, 41 of the 64 districts in the country were reported as having arsenic levels in groundwater exceeding $50 \mu \mathrm{g} / \mathrm{L}$, which is 5 times above the WHO guideline value. According to the British Geological Survey report one year later, arsenic contents in tube wells within the country were recorded as being relatively high, ranging from 50 to $3200 \mu \mathrm{g} / \mathrm{L}$ [44]. Meharg et al. (2003) reported that husked rice grain, collected in several districts in Bangladesh with high arsenic levels in ground water, had arsenic concentrations ranging from 0.058 to $1.83 \mathrm{mg} / \mathrm{kg}$, which indicated that, despite impact due to mining, crop cultivation in the country faces serious problems with arsenic-contaminated aquifers.

\section{Thailand Case Study}

Rice has long been a staple food for Thai citizens, with white rice and sticky rice being commonly consumed by more than $80 \%$ and $40 \%$ of the population, respectively [3]. Thailand is also one of the largest annual exporters of rice in the world, with annual export volume in the period 2015-2017 averaging 10.5 million metric tonnes, and expected to increase to 12.9 million metric tonnes by 2027 [45]. In the global mineral marketplace, the country is one of the leading producers of cement, feldspar, and gypsum. Thailand produces a variety of metals - such as copper, gold, iron ore, manganese, silver, tin, tungsten, and zinc - with export value in 2015 of USD 9.2 billion, representing $4.3 \%$ of Thailand's total exports [46]. However, due to mining activities, health problems have been recognized in the vicinities of several mining sites. In 2015, 59 out of 1004 villagers tested in the vicinity of a gold mine in Phichit province had high levels of cyanide in their blood. Cyanide is used to extract gold from ore and can be volatized into the air, lingering for long periods of time and causing local residents to experience acute inhalation toxicity [47]. In the same year, the Central Institute of Forensic Science of Thailand found that 282 villagers living around the Chatree mine, which is the first and largest gold mine in Thailand, had excessive levels of potentially toxic elements in their blood-due to the polluted surface water and rice fields-which increases the risk of cancer, DNA abnormalities, and birth defects [48].

Table 3 illustrates the total arsenic content in white rice and sticky rice (which are the most commonly used types of rice in Thailand) from vicinities of mining sites. In general, the difference between total arsenic concentration in polished sticky rice and polished white rice from investigated areas was insignificant. Arsenic levels in both white and sticky rice samples from mining areas in Thailand were found to be relatively higher than those of rice from markets in over 10 Thai provinces. The highest concentration was found in Ron Phibun, a district in Nakorn Si Thammarat, southern Thailand. This area, located within 
the Southeast Asian Tin Belt, has a mining history dating back more than 100 years. As a consequence of this extensive duration of mine operation, ore-processing waste and mine tailings, rich in arsenopyrite, were generated and spread to the vicinity of the mine. In 1987, health problems related to arsenic exposure through drinking water were first reported in the region and, in 1990, the mining site was officially closed [49]. The arsenic concentration in rice grain around this abandoned mine was recorded to range widely between 0.291 and $1.361 \mathrm{mg} / \mathrm{kg}$, which is lower than the Thai Food and Drug Administration (FDA) maximum permitted arsenic level $(2 \mathrm{mg} / \mathrm{kg})$; however, it exceeded the recommended limits for both husked rice $(0.35 \mathrm{mg} / \mathrm{kg})$ and polished rice $(0.2 \mathrm{mg} / \mathrm{kg})$ [50].

The Mae Tao sub-district lies in Mae Sot District, Tak province, in northwestern Thailand. Owing to the mineral-rich and fertile soil, Mae Tao is the leading growing region in Mae Sot district with a cultivation area of over 3500 ha. However, this sub-district is the downstream floodplains of the Mae Tao watershed [51], and the irrigation source for crops in Mae Tao is from Mae Tao Creek, which passes through the upstream Zn mines [52]. As a result, waste generation from the $\mathrm{Zn}$ mines was transported downstream and was later reported to be a significant source of soil, water, and plant contamination in this area, leading to the presence of elevated concentrations of potentially toxic elements [53]. Cd concentrations in rice and soil were reported in the range of 0.01 to $7.75 \mathrm{mg} / \mathrm{kg}$ and 0.1 to $284 \mathrm{mg} / \mathrm{kg}$, respectively [53]. The mean value of arsenic levels in polished white rice and polished sticky rice were also found to be high at 0.316 and $0.336 \mathrm{mg} / \mathrm{kg}$, respectively.

Table 3. Total arsenic concentration in rice samples from several regions in Thailand.

\begin{tabular}{|c|c|c|c|c|c|}
\hline Location & Type of Rice & $\mathbf{n}$ & Mean (mg/kg) & Range (mg/kg) & Ref. \\
\hline \multicolumn{6}{|l|}{ Gold mine in Wang } \\
\hline Around gold mine & Polished sticky rice & & 0.34 & & [54] \\
\hline Under tailing pond & Polished sticky rice & & 0.19 & & [54] \\
\hline \multirow[t]{2}{*}{ Mae Tao sub-district } & Polished white rice & 31 & 0.316 & $0.193-0.462$ & [51] \\
\hline & Polished sticky rice & 28 & 0.336 & $0.137-0.612$ & [51] \\
\hline Ron Phibun & - & 5 & 0.682 & $0.291-1.361$ & [55] \\
\hline \multirow[t]{2}{*}{ Market } & Polished white rice & 30 & 0.125 & $0.088-0.220$ & [56] \\
\hline & Polished sticky rice & 30 & 0.136 & $0.087-0.262$ & [56] \\
\hline
\end{tabular}

-: not mentioned.

Wang Saphung district is located in Loei province, a northeastern rice cultivation region in Thailand with a cultivation area of over $143 \mathrm{~km}^{2}$. A gold mine was in operation from 2006 to 2017 and used the open-pit mining and benching method, covering a total area of $2.06 \mathrm{~km}^{2}$ [54,57]. In 2007, a tailings dam failure caused mining residue to flow into agricultural areas in the vicinity of the mine [58]. A water test conducted by the Pollution Control Department in 2008 showed a dangerous level of arsenic in groundwater $(0.04 \mathrm{mg} / \mathrm{L})$. The follow-up investigation of groundwater in 2009 by the Groundwater Analysis Division, Department of Groundwater Resources, also reported values exceeding the standard level of arsenic ( $0.03 \mathrm{mg} / \mathrm{L})$ [59]. In 2010, a blood test of 474 residents in six villages around the gold mine revealed that 38 and 84 residents had mercury and cyanide levels exceeding the standard, respectively [57]. Neeratanaphan et al. (2015) reported that the mean values of arsenic concentration in polished sticky rice from around the gold mine and under the trailing pond were 0.34 and $0.19 \mathrm{mg} / \mathrm{kg}$, respectively [54]. Samples from around this gold mine also recorded the highest mean arsenic level found among the studied mining areas in Thailand, and were two times higher than that of market samples from all over the country.

\section{Vietnam Case Study}

Vietnam is one of the world's leading rice producers and consumers. According to the International Rice Research Institute, rice production accounts for $82 \%$ of the country's 
cultivated land area, with $52 \%$ of Vietnam's rice production in the Mekong River Delta, and $18 \%$ in the Red River Delta [60]. However, various geological studies have also indicated that the country is enriched with a great variety of mineral deposits. Vietnam possesses some of the largest global reserves of phosphate (apatite), bauxite, rare earths, and large, commercially viable deposits of oil, coal, gold, gemstones, copper, zinc, tin, chromite, manganese, titanium (mineral sands), graphite, and other minerals [61].

Cau River, which is one of the most polluted rivers in Vietnam, is the main river of the Thai Binh River system that joins with the Red River system and carries alluvium to create the Red River Delta, passing through several cities and industrialized areas. The upper Cau River and its tributaries are severely impacted by mining activities, especially from Thai Nguyen province, causing the lower part of the river to contain high concentrations of pollutants from the untreated water [62]. Located in Dai Tu District (Thai Nguyen), the multi-metal deposit represents one of the largest tungsten mines in the world, with an area of $9.21 \mathrm{~km}^{2}$. The mine was operated by traditional manual mining methods over a few decades [63] before official operations began in 2013, with mining reserves of 65 million tons of ore. A study by Nguyen et al. (2018) claimed that the arsenic content in three-quarters of the groundwater and most vegetable samples from the vicinity of the mine exceeded the guideline recommended by World Health Organization (WHO) [64]. Ko et al. (2020) reported that the total arsenic concentration in rice grains from this area ranged from 0.2 to $0.9 \mathrm{mg} / \mathrm{kg}$, and the mean value was 2 times higher than the Codex standard for polished rice [65]. Although the Red River Delta and Mekong River Delta are reported to have sediments and aquifers that are naturally enriched with arsenic [35,37], the result from the mining area was notably higher than those of these two main rice-cultivating regions, with mean values of arsenic concentration of 0.18 and $0.13 \mathrm{mg} / \mathrm{kg}$ in the Mekong River and Red River, respectively.

Dai Lam village is situated on the rim of the Cau River, which is downstream of the multi-metal mine. According to Hahn (2016), the mean value of arsenic concentration in rice in this region was $0.23 \mathrm{mg} / \mathrm{kg}$. It can be seen from the results in Table 4 that there is a gradual decrease in the arsenic level in rice from upstream locations to the rim of the Cau River, and finally to the Red River Delta, indicating the impact of mining activity on the concentration of arsenic in rice.

Table 4. Total arsenic concentration in polished rice from several regions in Vietnam.

\begin{tabular}{cccccc}
\hline Location & Sampling Period & $\mathbf{n}$ & Mean (mg/kg) & Range (mg/kg) & Ref. \\
\hline Mekong River Delta & 2017 & 78 & 0.18 & $0.08-0.56$ & {$[66]$} \\
Red River Delta & 2017 & 19 & 0.13 & 0.23 & {$[66]$} \\
Dai Lam (Bac Ninh) & 2016 & 11 & 0.4 & $0.2-0.9$ & {$[62]$} \\
Multi-metal mine (Dai Tu) & 2019 & & 0.29 & $0.18-0.40$ & {$[65]$} \\
Thuong Quan commune & 2019 & & {$[67]$} \\
\hline
\end{tabular}

Located further north from Thai Nguyen, Bac Kan province also possesses large mineral potential with 273 mines and lead and zinc reserves estimated to weigh more than 25 million tonnes [68]. In this region, Thuong Quan commune contains a wealth of small mines that are close to several rivers flowing through the province. Local households in this commune also settle along streams near mining sites, which can likely lead to exposure to metals and metalloids, as well as other pollutants from mining activities [67]. Tran et al. (2020) reported that the arsenic content in soil samples from this area had a range of 15.6 to $27.2 \mathrm{mg} / \mathrm{kg}$, which was slightly higher than the Vietnamese standard for agriculture soil $(15 \mathrm{mg} / \mathrm{kg})$. The study also pointed out that arsenic levels in rice samples from this commune exceeded the standard for arsenic in polished rice [50], with a mean value of $0.29 \mathrm{mg} / \mathrm{kg}$ and a range of 0.18 to $0.40 \mathrm{mg} / \mathrm{kg}$. Although the contamination in Thuong Quan was nowhere near as severe as in Dai Tu district, the mean value from this site was higher than those from other studied areas in the Vietnam case study, except for the multi-metal mine in Dai Tu. 


\section{Indonesia Case Study}

For decades, the mining industry has made a significant contribution to the Gross Domestic Product (GDP) of Indonesia and to various components of the national income. The country was the third largest global producer of mined tin in 2006, accounting for $18 \%$ of the world's production and $17 \%$ of the world's reserves. Indonesia was also responsible for significant proportions of the world's mine-produced nickel, copper, nitrogen, and gold [69]. It has become one of the crucial countries for artisanal, small-scale gold mining in Southeast Asia, and, in Indonesia, these activities usually take place at upland areas around rice paddy fields, which results in potentially toxic elements being carried by water flow to lowland areas [70]. Therefore, contamination by these compounds, especially mercury, has been of public concern in the country and several studies have reported excessive levels of mercury in soil, water, and plant samples around these small-scale gold mines [71-75]. Abbas et al. (2017) also stated that mercury levels in the hair of gold workers was directly proportional to the number of working years, and several neurological symptoms were found in most miners in the Makassar gold mine [76].

Along the same lines as mercury, arsenic appears to be a potential threat to public health in the country. A study by Rahman et al. (2019) on the health risk assessment of toxic chemicals associated with the Gunung Pongkor mine concluded that, after mercury and chromium, arsenic was the third most crucial pollutant at this site [77]. Located about $80 \mathrm{~km}$ south of Jakarta, the Gunung Pongkor gold-silver mine covers a total area of $112 \mathrm{~km}^{2}$ in Bogor Regency, which is a mineral-rich region of the country. Gold-silver deposits in Gunung Pongkor were proclaimed to contain a large reserve of 1.3 million ounces and attracted artisanal miners soon after the exploitation in 1992. Illegal mining activities took place afterwards at this site, which is situated upstream of the Cikaniki, Ciguha, and Cisarua rivers that are used by local inhabitants for daily purposes [78]. The high levels of potentially toxic elements in surface water and ground water in this region were explained to be rooted in not only weathered natural mineral rocks but also mining activities. Table 5 presents arsenic level in several rice samples in Indonesia with Gunung Pongkor as the mining-impacted site. The mean value of arsenic concentration in rice samples from the vicinity of the mine was reported to be extremely high at $2.27 \mathrm{mg} / \mathrm{kg}$ in 2014. Although a study conducted 2 years later determined this figure to be lower $(1.817 \mathrm{mg} / \mathrm{kg})$, this value was still far above the Indonesian National Standard for arsenic in rice (SNI No 7387) [79] and arsenic levels in samples from five rice production provinces in Indonesia [80]. In addition, it was reported that several detrimental health effects related to exposure to arsenic through the ingestion of drinking water and foods (rice, vegetables, fruit, fish) had already been observed in the adult residents in this region [78]. These data actively demonstrate the negative impact of mining activities on food crops, as well as human health, and immediate action should be taken on illegal mining operation and waste treatment to reduce health risk in this area.

Table 5. Total arsenic concentration in rice samples in Indonesia.

\begin{tabular}{ccccc}
\hline Location & Sampling Period & Mean $(\mathbf{m g} / \mathbf{k g})$ & Range $(\mathbf{m g} / \mathbf{k g})$ & Ref. \\
\hline Gunung Pongkor & 2014 & 2.27 & $0.352-3.216$ & {$[78]$} \\
Indonesia overall & 2016 & 1.817 & & {$[79]$} \\
\hline
\end{tabular}

\section{Korea Case Study}

Since 2010, Korea has made itself one of the regional and global leaders of mineral and metal production [81]. According to the 2010 Annual Report of Environmental Status in Mining Areas from The Korean Ministry of Trade, Industry, and Energy, there were approximately 5400 existing mines and more than $85 \%$ of them were left unmanaged without any minimum safety precautions, leading to pollution of the surrounding environment [82]. Risk assessment carried out in a number of mining-affected sites throughout the country, as well as several research studies, revealed the existence of health threats to local inhabitants 
of these areas [83-86]. Lim et al. (2008) concluded that 3 out of 1000 residents in the vicinity of the Songcheon Au-Ag mine could develop cancer due to long-term exposure to arsenic in water, soil, and plants near the mine [83].

Numerous studies have been conducted to investigate the extent and degree of arsenic contamination in crop plants derived from mining activities in Korea. Table 6 illustrates the concentrations of total arsenic in polished rice in the vicinity of several abandoned mines of the country over more than 40 years. The mean arsenic level in rice samples from mining-contaminated sites in Korea varied between 0.04 and $0.41 \mathrm{mg} / \mathrm{kg}$. While the Codex Alimentarius Commission recommends that the level of arsenic in polished rice should not be over $0.2 \mathrm{mg} / \mathrm{kg}$ [50], many of the results exceeded this threshold, and are much higher than the concentration in non-contaminated sites according to research conducted in 2013 with 100 rice samples from all over Korea where the soil was not contaminated. Arsenic concentrations in rice from near the Okdong $(0.17 \mathrm{mg} / \mathrm{kg})$ and Dongil $(0.15 \mathrm{mg} / \mathrm{kg})$ mines, from 2000 to 2001, were considerably higher than the mean value in the same period from Gyeongbuk province $(0.119 \mathrm{mg} / \mathrm{kg})$ [87], where these two mines are located. These data can be viewed as evidence proving that mining activity is one culprit causing the increase in arsenic content in rice grown around mining areas of the country.

Considering that arsenic contamination is an inevitable consequence of gold-mining activities, according to Barcelos et al., most of the studies in Korea were carried out with samples from the vicinity of gold mines [88]. The highest mean value recorded was from the Myeongbong gold mine in 2005, with a maximum arsenic concentration of $0.72 \mathrm{mg} / \mathrm{kg}$. Lee et al. (2008) stated that, after closing, nearly $11,000 \mathrm{~m}^{2}$ of tailings were left behind without proper treatment, and the unprotected mining waste was dispersed downhill in the vicinity of this mine by wind and water [89]. The Munmyeong silver-gold mine was also considered a significantly contaminated site due to the tailing dam failure caused by a typhoon in 2002, despite the fact that the mine had not been in operation for nearly 80 years. Arsenic concentrations in soil and rice samples from this mine were determined to be significantly elevated, with ranges of 16.56 to $704.0 \mathrm{mg} / \mathrm{kg}$ and 0.124 to $0.442 \mathrm{mg} / \mathrm{kg}$, respectively [90,91]. Apart from gold mining areas, the Dalsung copper mine also exhibited noticeable result, the reason being that the site was greatly affected not only by the mining industry, but also by volcanic activity, with the presence of arsenopyrite (FeAsS) in ore minerals. Arsenic levels in rice from the vicinity of this mine were therefore relatively high, with a mean value of $0.314 \mathrm{mg} / \mathrm{kg}$, according to Kwon et al. [91]. Mining activities in the Sambo lead-zinc mine also represented a potential health threat to the local residents. The mining operation stopped in 1991 and one of the tailings reservoirs was exposed to the atmosphere until 1992, then simply buried with soil at a depth of about $40 \mathrm{~cm}$ to prevent loss [92]. The major source of pollution in the Sambo mine was leachate, from mine waste, deposited in the main tailings dam and leading to potentially toxic elements in the stream sediments and water in the vicinity of the mine [93]. Rice samples from the Sambo mine were reported to be contaminated with relatively excessive arsenic levels, ranging from 0.104 to $0.774 \mathrm{mg} / \mathrm{kg}$. However, the mine was subsequently proclaimed to have undergone tailings removal and damage prevention projects [92,93], which would make it possible to reduce the contamination in crop plants from the site.

Study results from the Okdong and Yeongdae mines showed that there was an upward trend in the arsenic level in rice samples collected from these two sites. In particular, in the Yeongdae gold-silver mine, the concentration of arsenic stood at $0.110 \mathrm{mg} / \mathrm{kg}$ in 1988 , then doubled after 25 years and surpassed the maximum limit for arsenic in polished rice [50]. These results suggest that the contamination situation in several mining sites in Korea has not yet been alleviated, leading to arsenic accumulation in soil and plants, and causing serious threats to the health of local residents. In the case of the Gubong mine, the arsenic level in rice was recorded as being relatively high at $0.30 \mathrm{mg} / \mathrm{kg}$ more than 20 years ago, indicating that, if the tailings were not treated properly, as was the condition in the Yeongdae mine, the accumulation could subsequently exert worse detrimental impacts on the health of inhabitants living in the vicinity. 
Table 6. Total arsenic concentration in polished rice sampled from mining sites in Korea.

\begin{tabular}{|c|c|c|c|c|c|c|}
\hline Location & Major Metals & $\begin{array}{l}\text { Sampling } \\
\text { Period }\end{array}$ & $\mathbf{n}$ & Mean (mg/kg) & Range (mg/kg) & Ref. \\
\hline Gubong mine & $\mathrm{Au} \mathrm{Ag}$ & 1997 & \multirow{3}{*}{2} & 0.30 & & [94] \\
\hline \multirow{2}{*}{ Okdong mine } & \multirow{2}{*}{$\mathrm{Cu}, \mathrm{Pb}, \mathrm{Zn}$} & 2000-2001 & & 0.17 & & [95] \\
\hline & & $2001-2002$ & & 0.24 & & [85] \\
\hline Hwacheon mine & $\mathrm{Au}, \mathrm{Ag}, \mathrm{Pb}, \mathrm{Zn}$ & 2001-2002 & 3 & 0.23 & & [85] \\
\hline Dongil mine & $\mathrm{Au}, \mathrm{Ag}, \mathrm{Cu}, \mathrm{Zn}$ & 2000-2001 & 2 & 0.15 & & [95] \\
\hline Dongjeong mine & $\mathrm{Au}, \mathrm{Ag}, \mathrm{Cu}$ & $2002-2003$ & 3 & 0.20 & $0.12-0.28$ & [96] \\
\hline Boeun mine & Coal & 2002-2004 & & 0.04 & & [97] \\
\hline Sanggok mine & $\mathrm{Au}, \mathrm{Ag}, \mathrm{Pb}, \mathrm{Zn}$ & $2002-2004$ & & 0.08 & $0.04-0.12$ & [97] \\
\hline Myeongbong mine & $\mathrm{Au}, \mathrm{Ag}$ & 2005 & 5 & 0.41 & $0.24-0.72$ & [89] \\
\hline \multirow[t]{2}{*}{ Jukjeon mine } & \multirow[t]{2}{*}{$\mathrm{Au}, \mathrm{Ag}$} & 2007 & 11 & 0.221 & & [86] \\
\hline & & 1988 & 50 & 0.110 & $0.029-0.193$ & [98] \\
\hline \multirow[t]{2}{*}{ Yeongdae mine } & \multirow[t]{2}{*}{$\mathrm{Au}, \mathrm{Ag}$} & 2003 & 63 & 0.126 & $0.043-0.286$ & [98] \\
\hline & & 2013 & 10 & 0.218 & $0.162-0.280$ & [98] \\
\hline Sambo mine & $\mathrm{Pb}, \mathrm{Zn}$ & 2014 & 10 & 0.247 & $0.104-0.774$ & [91] \\
\hline Munmyeong mine & $\mathrm{Au}, \mathrm{Ag}$ & 2014 & 10 & 0.217 & $0.124-0.442$ & [91] \\
\hline Dalsung mine & $\mathrm{Cu}, \mathrm{W}$ & 2014 & 10 & 0.314 & $0.212-0.454$ & [91] \\
\hline Yaro mine & $\mathrm{Au}$ & 2019 & 6 & 0.03 & & [82] \\
\hline Non-contaminated sites & & 2013 & 100 & 0.11 & $0.03-0.33$ & [99] \\
\hline
\end{tabular}

\section{Conclusions}

Rice crops in all of the studied mining-impacted regions have been seriously contaminated by arsenic. In particular, China, as the largest rice consumer, was found to be the worst affected, as excessive levels of arsenic in rice were found in numerous places where mining activities take place within the country. In Korea, mines abandoned for over 40 years may still cause health threats to local citizens due to natural processes from the distribution of tailings and mine drainage that were not properly treated in the vicinity of the mines. Although arsenic contamination in rice from India, Bangladesh, and Vietnam are largely related to the naturally contaminated aquifers, mining activities still present considerable potential hazards to residents. Elevated levels of arsenic in crop samples, as well as serious health problems, have been observed in several Thai mining areas. In Indonesia, artisanal small-scale gold mining has generated a variety of toxicants, including arsenic, and related adverse health effects have been observed in local inhabitants. Due to the harmful health consequences caused by the accumulation of arsenic in rice plants, and eventually in humans, it is highly recommended that proper waste treatment, as well as remediation, should be carried out immediately to reduce the transport of potentially toxic elements from mining sites to their vicinities.

Author Contributions: Writing—original draft preparation, A.T.P.H. and N.P.; writing—review and editing, A.T.P.H. and K.-W.K.; supervision, K.-W.K. All authors have read and agreed to the published version of the manuscript.

Funding: This work was supported by GIST Research Institute (GRI) via a grant funded by the GIST (K13680) in 2021.

Data Availability Statement: All data presented in this study are available in the text and enclosed tables.

Acknowledgments: The authors are sincerely grateful to the journal editors and the three anonymous reviewers for their useful comments in the revision of this manuscript.

Conflicts of Interest: The authors declare no conflict of interest. 


\section{References}

1. Fukagawa, N.K.; Ziska, L.H. Rice: Importance for Global Nutrition. J. Nutr. Sci. Vitaminol. 2019, 65, S2-S3. [CrossRef]

2. Signes-Pastor, A.J.; Carey, M.; Meharg, A.A. Inorganic arsenic in rice-based products for infants and young children. Food Chem. 2016, 191, 128-134. [CrossRef] [PubMed]

3. FAO. FAO Rice Market Monitor 2018; FAO: Rome, Italy, 2018.

4. Zhuang, P.; Mcbride, M.; Xia, H.; Li, N.; Li, Z.A. Health Risk from Heavy Metals via Consumption of Food Crops in the Vicinity of Dabaoshan Mine, South China. Sci. Total Environ. 2009, 407, 1551-1561. [CrossRef] [PubMed]

5. He, S.; Wang, X.; Wu, X.; Yin, Y.; Ma, L.Q. Using rice as a remediating plant to deplete bioavailable arsenic from paddy soils. Environ. Int. 2020, 141, 105799. [CrossRef] [PubMed]

6. Majumder, S.; Banik, P. Geographical variation of arsenic distribution in paddy soil, rice and rice-based products: A meta-analytic approach and implications to human health. J. Environ. Manag. 2019, 233, 184-199. [CrossRef]

7. Fan, Y.; Zhu, T.; Li, M.T.; He, J.; Huang, R. Heavy metal contamination in Soil and Brown Rice and Human Health Risk Assessment near Three Mining Areas in Central China. J. Healthc. Eng. 2017, 3, 1-9. [CrossRef]

8. Li, X.; Xie, K.; Yue, B.; Gong, Y.; Shao, Y.; Shang, X.; Wu, Y. Inorganic arsenic contamination of rice from Chinese major rice-producing areas and exposure assessment in Chinese population. Sci. China Chem. 2015, 58, 1898-1905. [CrossRef]

9. Cai, L.M.; Xu, Z.C.; Qi, J.Y.; Feng, Z.Z.; Xiang, T.S. Assessment of exposure to heavy metals and health risks among residents near Tonglushan mine in Hubei, China. Chemosphere 2015, 127, 127-135. [CrossRef]

10. Farooki, M. China's Mineral Sector and the Belt $\mathcal{E}$ Road Initiative; Strategic Dialogue on Sustainable Raw Materials for Europe: Beijing, China, 2018.

11. Yi, T.; Xiang, P. An Emergy analysis of paddy farming in Hunan Province, China: A new perspective on sustainable development of agriculture. J. Integr. Agric. 2016, 15, 2426-2436. [CrossRef]

12. Song, D.; Zhuang, D.; Jiang, D.; Fu, J.; Wang, Q. Integrated Health Risk Assessment of Heavy Metals in Suxian County, South China. Int. J. Environ. Res. Public Health 2015, 12, 7100-7117. [CrossRef] [PubMed]

13. Liu, H.; Probst, A.; Liao, B. Metal contamination of soils and crops affected by the Chenzhou lead/zinc mine spill (Hunan, China). Sci. Total Environ. 2005, 399, 153-166. [CrossRef]

14. Codex Alimentarius Commission. Report of the 10th Session of the Codex Commitee on Contaminants in Foods (REP16/CF); Codex Alimentarius Commission: Rome, Italy, 2016.

15. Tang, J.; Liao, Y.; Yang, Z.; Chai, L.; Yang, W. Characterization of arsenic serious-contaminated soils from Shimen realgar mine area, the Asian largest realgar deposit in China. J. Soils Sediments 2016, 16, 1519-1528. [CrossRef]

16. Li, L.; Zeng, X.; Bai, L.; Li, S. Soil arsenic content and its health risk assessment for agricultural products in the region surrounding Shimen arsenic sulphide mine. Chin. J. Appl. Ecol. 2010, 21, 2946-2951. (In Chinese)

17. Li, J.H.; Dong, F.; Lu, Y.; Yan, Q.; Shim, H. Mechanisms controlling arsenic uptake in rice grown in Mining Impacted Regions in South China. PLoS ONE 2014, 9, e108300. [CrossRef] [PubMed]

18. Liu, C.; Yu, H.; Liu, C.; Li, F.; Xu, X.; Wang, Q. Arsenic availability in rice from a mining area: Is amorphous iron oxide-bound arsenic a source or sink? Environ. Pollut. 2015, 199, 95-101. [CrossRef] [PubMed]

19. Lei, M.; Zeng, M.; Wang, L.; Williams, P.N.; Sun, G. Arsenic, lead, and cadmium pollution in rice from Hunan markets and contaminated areas and their health risk assessment. Acta Sci. Circumstantiae 2010, 30, 2314-2320. (In Chinese)

20. Zeng, F.; Wei, W.; Li, M.; Huang, R.; Yang, F.; Duan, Y. Heavy Metal Contamination in Rice-Producing Soils of Hunan Province, China and Potential Health Risks. Int. J. Environ. Res. Public Health 2015, 12, 15584-15593. [CrossRef]

21. Wu, F.; Fu, Z.; Liu, B.; Mo, C.; Chen, B.; Corns, W.; Liao, H. Health risk associated with dietary co-exposure to high levels of antimony and arsenic in the world's largest antimony mine area. Sci. Total Environ. 2011, 409, 3344-3351. [CrossRef]

22. Lu, X.; Zhang, X. Environmental geochemistry study of arsenic in Western Hunan mining area, P.R. China. Environ. Geochem. Health 2005, 27, 313-320. [CrossRef]

23. Zhu, Y.; Sun, G.; Lei, M.; Teng, M.; Liu, Y.; Chen, N.; Wang, L.; Carey, A.M.; Deacon, C.; Raab, A.; et al. High Percentage Inorganic Arsenic Content of Mining Impacted and Nonimpacted Chinese Rice. Environ. Sci. Technol. 2008, 42, 5008-5013. [CrossRef]

24. Liu, C.; Luo, C.; Gao, Y.; Li, F.; Lin, L.; Wu, C.; Li, X. Arsenic contamination and potential health risk implications at an abandoned tungsten mine, southern China. Environ. Pollut. 2010, 158, 820-826. [CrossRef] [PubMed]

25. Yu, H.; Ding, X.; Li, F.; Wang, X.; Zhang, S.; Yi, J.; Liu, C.; Xu, X.; Wang, Q. The availabilities of arsenic and cadmium in rice paddy fields from a mining area: The role of soil extractable and plant silicon. Environ. Pollut. 2016, 215, 258-265. [CrossRef] [PubMed]

26. Liang, Y.; Yi, X.; Dang, Z.; Wang, Q.; Luo, H.; Tang, J. Heavy Metal Contamination and Health Risk Assessment in the Vicinity of a Tailing Pond in Guangdong, China. Int. J. Environ. Res. Public Health 2017, 14, 1557. [CrossRef] [PubMed]

27. Lu, Y.; Dong, F.; Deacon, C.; Chen, H.; Raab, A.; Meharg, A.A. Arsenic accumulation and phosphorus status in two rice (Oryza sativa L.) cultivars surveyed from fields in South China. Environ. Pollut. 2010, 158, 1536-1541. [CrossRef] [PubMed]

28. Hemavathi, M.; Prabakaran, K. ARIMA Model for Forecasting of Area, Production and Productivity of Rice and Its Growth Status in Thanjavur District of Tamil Nadu, India. Int. J. Curr. Microbiol. Appl. Sci. 2018, 7, 149-156. [CrossRef]

29. Chatterjee, B.; Chadha, R. Non-Fuel Minerals and Mining: Enhancing Mineral Exploration in India. Available online: https: //www.brookings.edu/wp-content/uploads/2020/04/Enhancing-Mineral-Exploration-in-India.pdf (accessed on 20 July 2020)

30. Tata Energy Research Institute Overview of Mining and Mineral Industry in India New Delhi; Centre for Environmental Studies: New Delhi, India, 2001. 
31. Porter GeoConsultancy Singhbhum Copper Belt-Chapri, Mosaboni, Pathargarh, Kendadih, Surda, Rakha, Dhobani, Jaduguda. Available online: http:/ / www.portergeo.com.au/database/mineinfo.asp?mineid=mn460 (accessed on 20 August 2020).

32. Giri, S.; Singh, A.K. Human health risk assessment due to dietary intake of heavy metals through rice in the mining areas of Singhbhum Copper Belt, India. Environ. Sci. Pollut. Res. 2017, 24, 14945-14956. [CrossRef]

33. Indian Ministry of Agriculture and Farmers Welfare Agricultural Statistics at a Glance 2018. Available online: http://agricoop. gov.in/sites/default/ files/agristatglance2018.pdf. (accessed on 18 July 2020).

34. Das, A. Ground Water Arsenic Contamination-A Study of Major Arsenic Affected Districts of West Bengal. Int. J. Sci. Res. 2015, 4, 2993-2996.

35. Shrestha, R.; Kafle, B.; Gurung, A.; Regmi, D. Arsenic in groundwater, soil and rice grain of Nepal. Int. J. Agric. Environ. Biores. 2017, 2.

36. Bhattacharya, P.; Samal, A.C.; Majumdar, J.; Santra, S.C. Accumulation of arsenic and its distribution in rice plant (Oryza sativa L.) in Gangetic West Bengal, India. Paddy Water Environ. 2010, 8, 63-70. [CrossRef]

37. FAPDA Country Fact Sheet on Food and Agriculture Policy Trends: Bangladesh. 2016. Available online: http://www.fao.org/3/ a-i5890e.pdf (accessed on 8 January 2021).

38. Yolanda, F.S. The Mineral Industry of Bangladesh. In U.S. Geological Survey Mineral Yearbook 2016; Bureau of Mines: Washington, DC, USA, 2020.

39. Rashid, H.O.; Shanto, M.A.S.; Roy, D.R.R.; Hossain, M.S.; Islam, M.S.; Hoque, M.M.M.; Urbi, Z. Impact of coal mining on soil, water and agricultural crop production: A cross-sectional study on Barapukuria coal mine industry, Dinajpur, Bangladesh. J. Environ. Sci. Res. 2014, 1, 1-6.

40. Halim, M.A.; Majumder, R.K.; Zaman, M.N.; Hossain, S.; Rasul, M.G.; Sasaki, K. Mobility and impact of trace metals in Barapukuria coal mining area, Northwest Bangladesh. Arab. J. Geosci. 2013, 6, 4593-4605. [CrossRef]

41. Bhuiyan, M.A.H.; Bodrud-Doza, M.; Rakib, M.A.; Saha, B.B.; Islam, S.M.D.-U. Appraisal of pollution scenario, sources and public health risk of harmful metals in mine water of Barapukuria coal mine industry in Bangladesh. Environ. Sci. Pollut. Res. 2021. [CrossRef] [PubMed]

42. Halim, M.A.; Majumder, R.K.; Zaman, M.N. Paddy soil heavy metal contamination and uptake in rice plants from the adjacent area of Barapukuria coal mine, northwest Bangladesh. Arab. J. Geosci. 2015, 8, 3391-3401. [CrossRef]

43. Islam, S.; Rahman, M.M.; Islam, M.R.; Naidu, R. Geographical variation and age-related dietary exposure to arsenic in rice from Bangladesh. Sci. Total Environ. 2017, 601-602, 122-131. [CrossRef]

44. Mukherjee, A.; Sengupta, M.K.; Hossain, M.A.; Ahamed, S.; Das, B.; Nayak, B.; Lodh, D.; Rahman, M.M.; Chakraborti, D. Arsenic contamination in groundwater: A global perspective with emphasis on the Asian scenario. J. Health Popul. Nutr. 2006, 24, 142-163.

45. OECD/FAO. OECD-FAO Agricultural Outlook", OECD Agriculture Statistics (Database); FAO: Rome, Italy, 2018.

46. Buteyn, S.D. The Mineral Industry of Thailand. In U.S. Geological Survey Mineral Yearbook 2015; USGS: Bangkok, Thailand, 2018.

47. Tran, Q.B.; Lohitnavy, M.; Phenrat, T. Assessing potential hydrogen cyanide exposure from cyanide-contaminated mine tailing management pratices in Thailand's gold mining. J. Environ. Manag. 2019, 249, 109357. [CrossRef]

48. Corporate Europe Observatory, the Transnational Institute and Friends of the Earth Europe/International. Destructive Mining Trumps Local Health and Environment. 10 Stories of How the Rich and Powerful Hijacked Justice. Available online: https: //www.tni.org/files/kingsgate-vs-thailand.pdf (accessed on 17 February 2021).

49. Kim, K.W.; Chanpiwat, P.; Hoang, T.H.; Phan, K.; Sthiannopkao, S. Arsenic geochemistry of groundwater in Southeast Asia. Front. Med. 2011, 5, 420-433. [CrossRef]

50. Codex Alimentarius Commission. Report of the 8th Session of the Codex Commitee on Contaminants in Foods (REP14/CF); Codex: Geneva, Switzerland, 2014.

51. Chanpiwat, P.; Hensawang, S.; Suwatvitayakorn, P.; Ponsin, M. Risk assessment of bioaccessible arsenic and cadmium exposure through rice consumption in local residents of the Mae Tao Sub-district, Northwestern Thailand. Environ. Geochem. Health 2019, 41, 343-356. [CrossRef]

52. Kosolsaksakul, P.; Farmer, J.G.; Oliver, I.W.; Graham, M.C. Geochemical associations and availability of cadmium (Cd) in a paddy field system, northwestern Thailand. Environ. Pollut. 2014, 187, 153-161. [CrossRef]

53. Suwatvitayakorn, P.; Ko, M.S.; Kim, K.W.; Chanpiwat, P. Human health risk assessment of cadmium exposure through rice consumption in cadmium-contaminated areas of the Mae Tao sub-district, Tak, Thailand. Environ. Geochem. Health 2020, 42, 2331-2334. [CrossRef]

54. Neeratanaphan, L.; Intamat, S.; Khammanichanh, A.; Sriuttha, M. Arsenic quantity on sticky rice (Oryza Sativa) of gold mining area. Koch Cha Sarn J. Sci. 2015, 37, 11-25.

55. Phimol, P.; Visuthismajarn, P.; Lin, C.; Rukkur, S. Assessment of arsenic concentrations and estimated daily intake of arsenic from rice (Oryza sativa) in Ron Phibun District, Southern Thailand. Int. J. Environ. Sci. Dev. 2017, 8, 517-520. [CrossRef]

56. Ruangwises, S.; Saipan, P.; Tengjaroenkul, B.; Ruangwises, N. Total and inorganic arsenic in rice and rice bran purchased in Thailand. J. Food Prot. 2012, 75, 771-774. [CrossRef]

57. Chutima, K. Leaching of Heavy Metals in Waste Rocks from Phu Tub Fah Gold Mine, Changwat Loei. Master's Thesis, Chulalongkorn University, Bangkok, Thailand, 2014.

58. Thanawattanawong, C. The Effects of Symbolism on a Social Movement: The Wang Sapung Gold Mining Conflict in Loei Province, Thailand. Soc. Sci. Asia 2019, 5, 81-92. 
59. Fuller, C.; Hurley, S.; Leung, M.; Winfield, L. Voices from the Margin: Economic, Social and Cultural Rights in the Northeast Thailand: Na Nong Bong; IDEA Publishing: London, UK, 2009.

60. Lacambra, C.; Molloy, D.; Lacambra, J.; Leroux, I.; Klossner, L.; Talari, M.; Cabrera, M.M.; Persson, S.; Downing, T.E.; Downing, E.; et al. Factsheet Resilience Solutions for the Rice Sector in Vietnam. Available online: https://publications.iadb.org/en/factsheetresilience-solutions-for-the-rice-sector-in-vietnam (accessed on 15 August 2020).

61. Nguyen, N.K. Mineral Resources Potential of Vietnam and Current State of Mining Activity. Appl. Environ. Res. 2014, 36, 37-46.

62. Hahn, C. Review of Arsenic Contamination and Human Exposure through Water and Food in Rural Areas in Vietnam. Ph.D. Thesis, Dresden University of Technology, Dresden, Germany, 2016.

63. Chu, K.N.; Nguyen, N.V.; Nguyen, B.D.; Le, S.T.; Tanaka, S.; Kang, Y.; Sakurai, K.; Iwasaki, K. Arsenic and Heavy Metal Concentrations in Agricultural Soils Around Tin and Tungsten Mines in the Dai Tu district, N. Vietnam. Water Air Soil Pollut. 2009, 197, 75-89.

64. Nguyen, T.P.M.; Nguyen, T.P.T.; Bui, T.H.; Nguyen, T.H. Concentration of arsenic in groundwater, vegetables, human hair and nails in mining site in the Northern Thai Nguyen province, Vietnam: Human exposure and risks assessment. Hum. Ecol. Risk Assess. Int. J. 2019, 25, 602-613. [CrossRef]

65. Ko, M.S.; Nguyen, H.T.; Kim, Y.G.; Bui, L.M.; Chanpiwat, P.; Nguyen, H.T.; Nguyen, H.A.; Le, T.H.; Nguyen, B.Q.; Nguyen, A.V.; et al. Assessment and source identification of As and Cd contamination in soil and plants in the vicinity of the Nui Phao Mine, Vietnam. Environ. Geochem. Health 2020, 42, 4193-4201. [CrossRef]

66. Nguyen, T.P.; Ruppert, H.; Pasold, T.; Sauer, B. Paddy soil geochemistry, uptake of trace elements by rice grains (Oryza sativa) and resulting health risks in the Mekong River Delta, Vietnam. Environ. Geochem. Health 2019, 42, 2377-2397. [CrossRef] [PubMed]

67. Tran, T.S.; Dinh, V.C.; Nguyen, T.A.H.; Kim, K.W. Heavy metals and arsenic concentrations in water, agricultural soil, and rice in Ngan Son district, Bac Kan province, Vietnam. Vietnamese J. Food Control 2020, 3, 270-282.

68. Viet Nam News. Bắc Kạn Province Struggles to Control Illegal Mining. Available online: https://vietnamnews.vn/environment/ 449075/bac-kan-province-struggles-to-control-illegal-mining.html (accessed on 10 February 2021).

69. Plaza-Toledo, M. The Mineral Industry of Indonesia. In U.S. Geological Survey Mineral Yearbook 2016; USGS: Drive Reston, VA, USA, 2020.

70. Novirsa, R.; Dinh, Q.P.; Ishibashi, Y.; Wispriyono, B.; Fukushima, S.; Arizono, K. The evaluation of mercury contamination in upland rice paddy field around artisanal small-scale gold mining area, Lebaksitu, Indonesia. J. Environ. Saf. $2019,10,119-125$.

71. Nakazawa, K.; Nagafuchi, O.; Kawakami, T.; Inoue, T.; Yokota, K.; Serikawa, Y.; Cyio, B.; Elvince, R. Human health risk assessment of mercury vapor around artisanal small-scale gold mining area, Palu city, Central Sulawesi, Indonesia. Ecotoxicol. Environ. Saf. 2016, 124, 155-162. [CrossRef]

72. Male, Y.T.; Reichelt-Brushett, A.J.; Pocock, M.; Nanlohy, A. Recent mercury contamination from artisanal gold mining on Buru Island, Indonesia-Potential future risks to environmental health and food safety. Mar. Pollut. Bull. 2013, 77, 428-433. [CrossRef]

73. Novirsa, R.; Dinh, Q.P.; Jeong, H.; Addai-Arhin, S.; Nugraha, W.C.; Hirota, N.; Wispriyono, B.; Ishibashi, Y.; Arizono, K. The dietary intake of mercury from rice and human health risk in artisanal small-scale gold mining area, Indonesia. Fundam. Toxicol. Sci. 2020, 7, 215-225. [CrossRef]

74. Sakakibara, M.; Sera, K. Mercury in Soil and Forage Plants from Artisanal and Small-Scale Gold Mining in the Bombana Area, Indonesia. Toxics 2020, 8, 15. [CrossRef]

75. Bentley, K.; Soebandrio, A. Dietary exposure assessment for arsenic and mercury following submarine tailings placement in Ratatotok Sub-district, North Sulawesi, Indonesia. Environ. Pollut. 2017, 227, 552-559. [CrossRef]

76. Abbas, H.H.; Sakakibara, M.; Sera, K.; Arma, L.H. Mercury Exposure and Health Problems in Urban Artisanal Gold Mining (UAGM) in Makassar, South Sulawesi, Indonesia. Geosciences 2017, 7, 44. [CrossRef]

77. Sari, N.; Wispriyono, B.; Novirsa, R.; Simanjuntak, J.; Fukushima, S.; Arizono, K.; Kusnoputranto, H. Risk assessment and community health profile among residents living in Artisanal and Small-scale Gold Mining site in Ciguha, Gunung Pongkor, Bogor. J. Environ. Saf. 2019, 10, 127-136.

78. Rahman, A.; Hananto, M.; Laelasari, E.; Adi, H.K.; Widodo, S.; Lasut, D. Health risk estimates from exposure to minerals in artisanal gold mining site in Gunung Pongkor, Bogor, Indonesia. In Full Paper Proceeding of International Trend in Multidisciplinary Academic Research 2014; Global Illuminators: Barcelona, Spain, 2014; Volume 1, pp. 467-490. ISBN 978-969-9948-24-4.

79. Zahra Food Intake Analysis and Estimated to Health Risk of People Living in Artisanal Gold Mining Gunung Pongkor, Bogor Regency, West Java Province. J. Ekol. Kesehat. 2016, 15, 150-159. (In Indonesian)

80. Codex Alimentarius Commission. Proposed Draft Maximum Levels for Arsenic in Rice. CX/CF 12/6/8-Add.1; Codex Alimentarius Commission: Maastricht, The Netherlands, 2012.

81. Shi, L. The Mineral Industry of the Republic of Korea. In Area Reports_International_Asia and the Pacific: U.S. Geological Survey Minerals Yearbook; Bureau of Mines: Washington, DC, USA, 2009; Volume 3, pp. 141-146.

82. Kim, M.-S.; Park, M.J.; Yang, J.H.; Lee, S.-H. Human Health Risk Assessment for Toxic Trace Elements in the Yaro Mine and Reclamation Options. Int. J. Environ. Res. Public Health 2019, 16, 5077. [CrossRef] [PubMed]

83. Lim, H.-S.; Lee, J.-S.; Chon, H.-T.; Sager, M. Heavy metal contamination and health risk assessment in the vicinity of the abandoned Songcheon Au-Ag mine in Korea. J. Geochemical Explor. 2008, 96, 223-230. [CrossRef] 
84. Ji, K.; Kim, J.; Lee, M.; Park, S.; Kwon, H.-J.; Cheong, H.-K.; Jang, J.-Y.; Kim, D.-S.; Yu, S.; Young Wook, K.; et al. Assessment of exposure to heavy metals and health risks among residents near abandoned metal mines in Goseong, Korea. Environ. Pollut. 2013, 178, 322-328. [CrossRef]

85. Lee, J.S.; Chon, H.T.; Myung, C.J. Toxic Risk Assessment and Environmental Contamination of Heavy Metals around Abandoned Metal Mine Sites in Korea. Key Eng. Mater. 2005, 277-279, 542-547. [CrossRef]

86. Park, J.H.; Choi, K.K. Risk assessment of Abandoned Jukjeon metal mine in South Korea following the Korean Guidelines. Hum. Ecol. Risk Assess. 2013, 19, 754-766. [CrossRef]

87. Jung, M.C. Background levels and daily intake of $\mathrm{As}, \mathrm{Cd}, \mathrm{Cu}, \mathrm{Pb}$ and $\mathrm{Zn}$ in white rice produced in Korea. Econ. Environ. Geol. 2003, 36, 357-363.

88. Barcelos, D.A.; Pontes, F.V.; da Silva, F.A.N.; Castro, D.C.; dos Anjos, N.O.; Castihos, Z.C. Gold mining tailing: Environmental availability of metals and human health risk assessment. J. Hazard. Mater. 2020, 397, 122721. [CrossRef] [PubMed]

89. Lee, J.S.; Lee, S.W.; Chon, H.T.; Kim, K.W. Evaluation of human exposure to arsenic due to rice ingestion in the vicinity of abandoned Myungbong Au-Ag mine site, Korea. J. Geochemical Explor. 2008, 96, 231-235. [CrossRef]

90. Kwon, J.C.; Park, H.J.; Jung, M.C. Correlation of Arsenic and Heavy Metals in Paddy Soils and Rice Crops around the Munmyung Au-Ag Mines. Econ. Environ. Geol. 2015, 48, 337-349. (In Korean) [CrossRef]

91. Kwon, J.C.; Nejad, Z.D.; Jung, M.C. Arsenic and heavy metals in paddy soil and polished rice contaminated by mining activities in Korea. Catena 2017, 148, 92-100. [CrossRef]

92. Kim, S.H.; Chon, H.T. Contamination of heavy metals in stream sediments in the vicinity of the Sambo Pb-Zn-Barite mine. J. Korean Inst. Min. Geol. 1993, 26, 217-226. (In Korean)

93. Yoon, K.W.; Jung, M.C.; Kim, J.W.; Jeon, S.W.; Han, S.H.; Lee, J.S.; Ji, W.H.; Kwon, O.H. Environmental assessment of water quality affected by mine drainage from tailings dam in the Sambo Pb-Zn Mine. J. Korean Soc. Miner. Energy Resour. Eng. 2020, 57, 12-23. [CrossRef]

94. Chon, H.T.; Ahn, J.S.; Jung, M.C. Heavy metal contamination around the abandoned Au-Ag and base metal mine sites in Korea. Econ. Environ. Geol. 2005, 38, 101-111.

95. Lee, J.S.; Chon, H.T. Exposure assessment of heavy metals on abandoned metal mine areas by ingestion of soil, crop plant and groundwater. J. Phys. IV 2003, 107, 757-760. [CrossRef]

96. Chung, E.H.; Lee, J.S.; Chon, H.T.; Sager, M. Environmental contamination and bioaccessibility of arsenic and metals around the Dongjeong Au-Ag-Cu mine, Korea. Geochem. Explor. Environ. Anal. 2005, 5, 69-74. [CrossRef]

97. Na, E.S.; Lee, Y.J.; Ko, K.Y.; Chung, D.Y.; Lee, K.S. Risk Assessment for Heavy Metals in Soil, Ground Water, Rice Grain nearby Abandoned Mine Areas. Korean J. Environ. Agric. 2013, 32, 245-251. [CrossRef]

98. Kwon, J.C.; Jeong, S.H.; Jung, M.C.; Kim, T.S. Seasonal Variation and Correlation between Soil and Crop Plant of Arsenic and Heavy Metal Concentrations in Paddy Fields around the Yeongdae Au-Ag Mine, Korea. J. Korean Soc. Miner. Energy Resour. Eng. 2013, 50, 212-226. [CrossRef]

99. Kim, D.Y.; Kim, J.Y.; Kim, K.H.; Kim, K.R.; Kim, H.S.; Kim, J.G.; Kim, W.I. Arsenic species in husked and polished rice grains grown at the non-contaminated paddy soils in Korea. J. Appl. Biol. Chem. 2018, 61, 391-395. [CrossRef] 